\title{
Reproductive output and consistency of source populations in the sea star Pisaster ochraceus
}

\author{
Eric Sanford $^{1, *}$, Bruce A. Menge ${ }^{2}$ \\ ${ }^{1}$ University of California Davis, Section of Evolution and Ecology, and Bodega Marine Laboratory, Bodega Bay, \\ California 94923, USA \\ ${ }^{2}$ Oregon State University, Department of Zoology, Corvallis, Oregon 97331, USA
}

\begin{abstract}
Although a common goal of marine reserves is to protect areas of high reproductive output, few studies have tested whether these source populations are spatially and temporally consistent. For 6 years between 1995 and 2005, we examined nutrient storage and gonad production in the sea star Pisaster ochraceus at 2 sites on the central coast of Oregon, USA. Sea stars accumulated energy in the pyloric caeca during a short season of intensive feeding (May to September). Within a site, the size of the pyloric caeca in the fall accurately predicted reproductive output during the following spring. In accord with hypotheses regarding bottom-up effects, the pyloric caeca were generally larger at the site where mussels were more abundant in the diet, indicating a greater accumulation of surplus energy. However, gonad indices were consistently $~ 50 \%$ lower at this site, suggesting striking differences in allocation to reproduction. This difference between populations was maintained despite marked variation among years in oceanographic conditions and reproductive output. These results suggest that (1) source populations may be consistent spatially, but (2) identifying those sources may be more complex than simply targeting areas with high quality resources and strong bottom-up influences. Rather, predicting patterns of per capita reproductive output may require a more detailed understanding of the causes of spatial variation in allocation to maintenance, growth, and reproduction.
\end{abstract}

KEY WORDS: Marine reserve $\cdot$ Bottom-up effects · Resource allocation $\cdot$ Reproduction $\cdot$ Marine Protected Area $\cdot$ El Niño

Resale or republication not permitted without written consent of the publisher

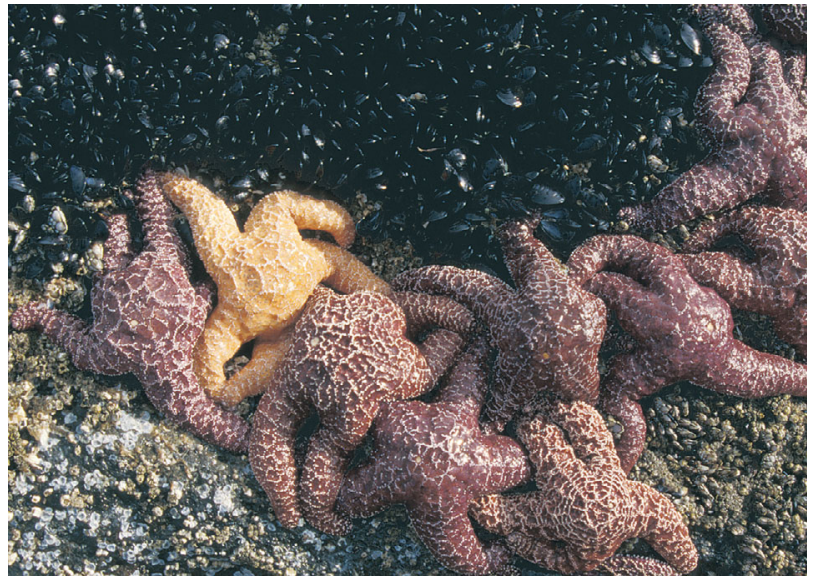

Sea stars Pisaster ochraceus feeding on mussels at Strawberry Hill, Oregon, USA.

Photo: E. Sanford

\section{INTRODUCTION}

Source populations and bottom-up effects

A common goal of marine reserve design is the protection of key sources of larval production that may replenish non-protected areas through larval export (Roberts 1997, Carr et al. 2003). However, the quality of reproductive habitat often varies among sites (Crowder et al. 2000, McIntyre \& Hutchings 2003, Leslie et al. 2005), and thus identifying sources of larval production has become one consideration in the placement of marine reserves (Quinn et al. 1993, Rogers-Bennett et al. 1995, Sala et al. 2002). In practice, incorporating this 
goal into reserve design has proved challenging because (1) spatial variation in the reproductive output of most marine species is poorly known (Roberts 1998, Crowder et al. 2000, Morgan 2001), and (2) prime reproductive habitat may change through time and/or differ among species (Roberts 1998).

A potential solution to these problems is suggested by studies linking oceanographic processes and bottom-up effects in marine communities. Recent work demonstrates that oceanographic processes can generate differences in the nearshore abundance of nutrients, phytoplankton, particulate food, and invertebrate larvae (see Menge 2000 for a review). Greater inputs at the base of marine food webs often fuel bottom-up increases in the abundance, growth, and reproduction of suspension-feeding invertebrates. These effects may propagate upward by supporting higher densities of consumers (Menge 1992, 2000). Moreover, because oceanographic gradients are often spatially and temporally consistent (e.g. related to coastal geomorphology, prevailing winds and currents), sites may vary predictably in the strength of bottom-up forces (Menge et al. 1997, Wing et al. 2003, Leslie et al. 2005). Thus, the problem of siting marine reserves in areas that represent source habitats for a large number of species might be overcome if (1) the availability of high quality resources is a persistent feature of some sites, and (2) bottom-up forces act to increase the abundance and reproductive output of species across multiple trophic levels. This approach to designating areas of protection has recently been suggested for the Galápagos Islands where Witman \& Smith (2003) hypothesized that productive upwelling sites may be source habitats with enhanced reproductive output of sessile suspension-feeding invertebrates, and, potentially, their predators (e.g. other invertebrates and fish).

Although logical, there is relatively little information available to evaluate whether reproductive output is increased among invertebrates and fish living at sites with high resource quality and/or quantity (Morgan 2001). For suspension-feeding invertebrates, performance may often be linked to pelagic food availability. For example, barnacles and mussels generally grow faster at sites where the abundance of phytoplankton or detritus is consistently higher (Bertness et al. 1991, Menge 1992, Sanford \& Menge 2001). Similarly, the reproductive output of barnacles is often higher in areas of high primary productivity (Bertness et al. 1991, Leslie et al. 2005). However, only a handful of studies have tested whether the reproductive output of marine consumers at higher trophic levels is sensitive to resource quality, and these studies have focused mostly on herbivores such as limpets and sea urchins (Rogers-Bennett et al. 1995, Kido \& Murray 2003, Wing et al. 2003; but see also McIntyre \& Hutchings 2003).

\section{Study system}

Between 1995 and 2005, we examined variation in the reproductive output of the sea star Pisaster ochraceus at 2 rocky intertidal sites on the central Oregon coast that differed strongly in prey quality. Pisaster is a top carnivore that can play a keystone role in maintaining the structure of rocky intertidal communities (Paine 1974, Menge et al. 1994). The abundance of Pisaster may be negatively impacted by disease (Eckert et al. 1999), parasites (Leighton et al. 1991), predators (Harrold \& Pearse 1980), and perhaps human collection or disturbance. Because of the community importance of Pisaster, management plans for rocky shores along the Pacific coast may wish to identify and protect Pisaster populations that could act as reproductive sources to replenish sites impacted by disturbance.

Pisaster is dioecious and iteroparous, with broadcast spawning occurring annually during the spring (April to June, depending on latitude and photoperiod; Feder 1956, Farmanfarmaian et al. 1958, Greenfield 1959, Mauzey 1966, Pearse \& Eernisse 1982). During periods of heavy feeding, Pisaster stores resources in extensions of the pyloric stomach called the pyloric caeca. Energy stored in the pyloric caeca appears to be converted into gonad production prior to spawning (Mauzey 1966, Harrold \& Pearse 1980, Lawrence \& Lane 1982). Like many temperate sea stars, Pisaster can have a strongly cyclical pattern of feeding activity (Mauzey 1966, Lawrence \& Lane 1982). In Washington state and Oregon, the abundance and feeding activity of Pisaster in the intertidal zone is concentrated during the spring and summer and greatly reduced during the late fall and winter (Mauzey 1966, Paine 1974, Menge et al. 1994, Navarette \& Menge 1996). As feeding activity declines starting in the late fall, the pyloric caeca shrink in size and the gonads grow larger prior to spawning (Mauzey 1966). A seasonal decline in Pisaster activity was not observed in Monterey Bay, California (Feder 1970) where the pyloric caeca of Pisaster were reported to grow in size along with the gonads until December/January, then decline prior to spawning (Greenfield 1959).

Given the life history of Pisaster, reproduction at northern sites may be a function of resources accrued primarily during the season of intensive feeding (spring and summer). Observers of other asteroid species have noted that individuals with large gonads are sometimes associated with areas of high resource quality (Crump 1971, Barker \& Xu 1991). For example, in New Zealand, the sea star Sclerasterias mollis had larger pyloric caecum and gonad indices at a site where scallops were the primary prey available than at a site where the diet consisted of gastropods and other small prey (Barker \& Xu 1991). When Pisaster occur at 
sites with abundant mussels and barnacles, the blue mussel Mytilus trossulus is the dominant prey in the diet, whereas acorn barnacles are rarely consumed (Sanford 1999, see also Feder 1970). This pattern of prey selection is consistent with data showing that mussels contain more tissue and have a higher caloric value than acorn barnacles (Menge 1972). A logical prediction of these bottom-up considerations is that the reproductive output of Pisaster should reflect the frequency of mussels in the diet.

In addition to variation in prey quality, surplus energy available in the pyloric caeca may also be influenced by temperature and other environmental effects on metabolism. For example, interannual variation in water temperature associated with patterns of upwelling may influence Pisaster reproduction (Sanford 2002). In laboratory studies, Pisaster held at $9^{\circ} \mathrm{C}$ (simulating continuous upwelling), or in a treatment that fluctuated between $9^{\circ} \mathrm{C}$ and $12^{\circ} \mathrm{C}$ every $2 \mathrm{wk}$ (simulating episodic upwelling), had pyloric caecum indices that were $25 \%$ greater than sea stars held at a constant $12^{\circ} \mathrm{C}$ (Sanford 2002). These results raise the question of whether reproductive output is stable in the face of environmental changes, such as those posed by El Niño events and longer-term oceanographic changes.

\section{Hypotheses}

Here, we quantify spatial and temporal variation in the reproductive output of Pisaster to explore whether potential source populations are predictable and stable through time. Specifically, we test 4 hypotheses: (1) Pisaster accumulate greater stores in the pyloric caeca at sites where the diet includes a greater frequency of high quality prey (mussels versus barnacles); (2) the size of the pyloric caeca at the end of the summer is an accurate predictor of reproductive output during the following spring; (3) interannual variation in the size of the pyloric caeca is reflected in gonad production; (4) nutrient storage and reproductive output are sensitive to interannual variation in oceanographic conditions.

\section{MATERIALS AND METHODS}

Study sites. Between 1995 and 2005, we examined nutrient storage and gonad production in Pisaster ochraceus at 2 wave-exposed, outer coast sites separated by $34 \mathrm{~km}$ on the central coast of Oregon, USA: Strawberry Hill $\left(44^{\circ} 15^{\prime} \mathrm{N}, 124^{\circ} 07^{\prime} \mathrm{W}\right)$ and the South Jetty in Newport, Oregon $\left(44^{\circ} 36^{\prime} \mathrm{N}, 124^{\circ} 04^{\prime} \mathrm{W}\right)$. Strawberry Hill ( $\mathrm{SH}$ ) is composed of extensive rocky benches, pools, and surge channels (Menge 1992). The Newport South Jetty (NSJ) is a human-made breakwater of large boulders that extends out approximately $1 \mathrm{~km}$ WSW from the shore and protects the south side of the entrance to Yaquina Bay. The area studied was on the outside of the jetty, approximately $200 \mathrm{~m}$ from shore, and was subject to wave exposure and winter storms comparable to SH (authors' pers. obs.).

Preliminary observations suggested that prey differed markedly between these locations. At $\mathrm{SH}$, patches of the blue mussel Mytilus trossulus and gooseneck barnacle Pollicipes polymerus were abundant in the low intertidal zone, and beds of the mussel M. californianus dominated the mid intertidal zone (Menge et al. 1994). Previous work identified SH as a site with seasonally high phytoplankton productivity and high rates of mussel recruitment and growth (Menge 1992, Menge et al. 1997). Mussels and gooseneck barnacles were uncommon at NSJ. Here, low intertidal surfaces were dominated by algal turf, coralline algae, and the clonal anemone Anthopleura elegantissima, and the most abundant prey were the acorn barnacles Balanus glandula and Chthamalus dalli on mid intertidal boulder faces.

Quantification of sea star diet. A permanent sampling area was established at both SH and NSJ consisting of $\sim 300 \mathrm{~m}^{2}$ of low intertidal rocky habitat. Each area was surrounded by deep channels and sand that likely discouraged large-scale movements of sea stars. We quantified sea star diet within the sampling areas during 5 periods (July 1995, May 1996, August 1996, May 2003, and April 2005) by placing two $30 \mathrm{~m}$ transects parallel to the water. We examined the first 100 sea stars within $1 \mathrm{~m}$ of each transect and noted all prey items that were being consumed. Consumed prey included (1) those that sea stars were actively feeding on (with the sea star's stomach everted), or (2) those that had been recently eaten (with remains and shells present at the edge of the sea star's mouth). If a sea star was feeding on one or more mussels, we measured the shell length of the largest mussel being consumed. We did not attempt to quantify between-site differences in the total amount of food consumed by Pisaster as this would have required frequent sampling when sea stars were submerged. The high wave energy of these sites made it impossible to sample sea stars at high tide.

Seasonal variation in the intertidal abundance of sea stars. Between May 1995 and February 1998, we recorded seasonal variation in the density of Pisaster ochraceus in permanently marked rectangular plots (mean area $\pm \mathrm{SE}=3.49 \pm 0.30 \mathrm{~m}^{2}$ ). Plots were located in the sampling area at $\mathrm{SH}(\mathrm{n}=11)$ and in an area located $1 \mathrm{~km}$ to the south (Bob Creek Wayside, $\mathrm{n}=15$ ). Plots were positioned on horizontal surfaces at +0.7 to 
+1.2 $\mathrm{m}$ above mean low low water (MLLW), just below the lower edge of the mussel bed. This is the tidal range where Pisaster were most commonly observed foraging at our sites (authors' unpubl. data). We recorded the density of sea stars within these plots every 2 wk during the spring and summer, and every 4 to 6 wk during the remainder of the year ( $\mathrm{n}=62$ dates). We did not quantify sea star density at NSJ on a routine basis because the irregular boulders were poorly suited for large, horizontal plots, and because wave swell made the jetty hazardous to access on a frequent schedule, especially during the fall and winter.

Sea star dissections. To characterize seasonal cycles in the pyloric caeca and gonads, we collected Pisaster at $\mathrm{SH}$ and NSJ during the first spring tide series of every other month between August 1995 and August 1997. To determine the time of spawning with greater precision, collections were also made during both May and June of 1996, 1997, and 1998. During the later part of this study, collections were made twice a year to capture annual peaks in the pyloric caeca (Fall 1997, 1998, 2002, and 2004) and gonads (May 1998, 1999, 2003, 2005). On each date, 12 individuals per site were collected haphazardly from the sampling area, weighed in the field using a digital balance, and retained if their wet weight fell within the range of 170 to $260 \mathrm{~g}$. This is the most common size class present at many sites along the central Oregon coast (Menge et al. 1994, E. Sanford unpubl. data). Pisaster reaches sexual maturity at 70 to $90 \mathrm{~g}$ wet weight (Menge 1975).

Following collection, sea stars were held in seawater tables at Hatfield Marine Science Center in Newport, Oregon, for $24 \mathrm{~h}$, and then dissected following established methods (Farmanfarmaian et al. 1958, Mauzey 1966). Prior to dissection, sea stars were anesthetized for 15 to $20 \mathrm{~min}$ in an isotonic solution of $\mathrm{MgCl}_{2}$ and seawater. Radial cuts along the aboral surface of each arm were made using scissors (Soft Touch Micro-Tip Scissors, Fiskars), and the gonads and pyloric caeca were removed. The eviscerated sea star was weighed and the removed organs were blotted on paper towels for $15 \mathrm{~min}$ to remove excess water. The volume of the pyloric caeca and gonads were determined by their displacement of known volumes of water in a graduated cylinder (Mauzey 1966). Following previous studies (Lawrence \& Lane 1982), the gonad and pyloric caecum indices were defined as the ratio of that organ's volume to eviscerated body weight $\times 100$. The specific gravity of the pyloric caeca, gonads, and sea water are essentially equivalent (Mauzey 1966), so that indices determined with either organ wet weight or volume are comparable (Lawrence $\&$ Lane 1982). The peak gonad index is assumed to accurately reflect reproductive output in asteroids because non-gametogenic material is minimal when the gonads are fully mature (Lawrence 1985).
Interannual variation in water temperature and mussel recruitment. Long-term studies at one of our sites (SH) provided an opportunity to test whether the reproductive output of Pisaster responded to interannual differences in water temperature and/or mussel recruitment. Two data-loggers (Optic StowAway or TidbiT loggers, Onset Computer) were attached in the low intertidal zone at $\mathrm{SH}$ and recorded temperature every $30 \mathrm{~min}$ during the months when Pisaster was accumulating energy in the pyloric caeca (May through August). These are also the primary months when coastal upwelling occurs along the central Oregon coast. For each high tide, we calculated the mean of all readings taken during a $4 \mathrm{~h}$ interval centered around each high tide (as estimated from NOAA tide charts).

Mussel recruit collectors were also attached in the low intertidal zone within the same sampling area at SH. Collectors were plastic mesh balls (SOS Tuffy pads, Clorox) deployed monthly ( $\mathrm{n}=5 \mathrm{mo}^{-1}$ ) throughout this study as part of a long-term monitoring program (Menge 1992, Barth et al. 2007). Collectors were returned to the laboratory and mussel recruits were counted under a dissecting microscope. Newly settled mussels could not be identified reliably to species and thus were grouped as Mytilus spp. However, previous studies indicate that blue mussels Mytilus trossulus settle abundantly in the low intertidal zone at $\mathrm{SH}$ during the fall, and patches of juvenile mussels (10 to $25 \mathrm{~mm}$ ) are conspicuous by winter (Menge et al. 1994, Navarrete \& Menge 1996). These patches are the major food source for Pisaster at SH (see 'Results'). To focus on the primary settlement season of $M$. trossulus, we analyzed collector data for the period of July to December of each year.

Statistical analysis. Organ indices were analyzed using analysis of variance (ANOVA). Within the range of individuals sampled (170 to $260 \mathrm{~g}$ wet weight), least squares linear regressions of condition (gonad volume, peak gonad index, pyloric caeca volume, peak pyloric caecum index) on eviscerated body weight were nonsignificant ( $p>0.20$ for most Site $\times$ Year combinations) . Thus, we did not use sea star weight as a covariate in our analyses. Variation in the fall pyloric caecum index was examined using ANOVA with Site and Year as fixed factors. Pyloric caecum indices were log transformed prior to analysis to improve homogeneity of variances. Gonad indices from May of each year were analyzed in a separate ANOVA with Site, Year, and Sex as fixed factors. These data met the assumptions of ANOVA reasonably well and were not transformed. To test whether organ indices varied between sites within specific years, we conducted separate $t$-tests using a Bonferroni adjusted critical $\alpha=0.0083$ to control for multiple comparisons across the 6 yr. 
Multiple linear regression analysis was used to test whether internannual variation in the pyloric caecum index at $\mathrm{SH}$ was a function of mussel recruitment and water temperature at that site. Mussel recruitment was calculated as the mean number of recruits per day per collector during the months of July to December (prior to Pisaster's primary feeding season, May to August). Three explanatory variables were tested in separate models as indicators of interannual variation in water temperature between May and August: the proportion of high tides $<10^{\circ} \mathrm{C}$, between 10 and $12^{\circ} \mathrm{C}$, and $>12^{\circ} \mathrm{C}$. All analyses were performed using JMP IN (version 5.1.2, SAS).

\section{RESULTS}

\section{Between-site differences in diet}

Pisaster diet differed markedly between Strawberry Hill and the Newport South Jetty (Fig. 1). Sea star diets within a site were consistent through time and thus diet data were pooled across years. At $\mathrm{SH}$, sea stars fed almost exclusively on the blue mussel Mytilus trossulus and the gooseneck barnacle Pollicipes polymerus. In contrast, $83 \%$ of feeding sea stars at NSJ preyed on the acorn barnacles Balanus glandula, Chthamalus dalli, and Semibalanus cariosus. Although some sea stars at NSJ also fed on M. trossulus, these mussels were generally recent recruits that were attached to the shells of barnacles. These recruits were smaller than the mussels consumed at $\mathrm{SH}$ (mean shell length $\pm \mathrm{SE}=8.55 \pm 0.32$ vs. $20.18 \pm$ $0.41 \mathrm{~mm}$; $t$-test, $\left.t_{513}=19.8, \mathrm{p}<0.001\right)$, and were probably consumed incidentally with barnacles.

\section{Seasonal variation in the intertidal activity of Pisaster}

The density of Pisaster in intertidal plots at $\mathrm{SH}$ and an adjacent location (Bob Creek Wayside) was strongly seasonal during the 3 yr of observation (Fig. 2). Data from these locations were pooled because all plots were located within 1 $\mathrm{km}$ of the shore and displayed the same seasonal trends in sea star abundance. From May to September, the mean density \pm SE of Pisaster was $4.77 \pm 0.16$ ind. $\mathrm{m}^{-2}$. From November to March, the mean density was $77 \%$ lower $(1.11 \pm 0.06$ ind. $\mathrm{m}^{-2}$ ). A similar seasonal decline in Pisaster density was noted at NSJ during the regular collection of sea stars for dissection

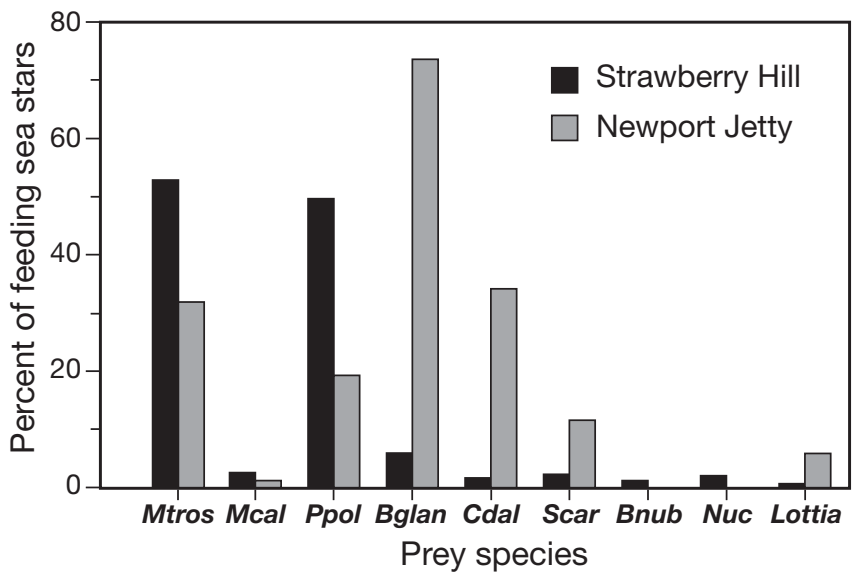

Fig. 1. Pisaster ochraceus. Diet of P. ochraceus at Strawberry Hill and Newport South Jetty, Oregon, USA showing the percent of sea stars feeding on prey species. For mussels: Mtros = Mytilus trossulus, $\mathrm{Mcal}=\mathrm{M}$. californianus; for barnacles: Ppol = Pollicipes polymerus, Bglan = Balanus glandula, $C d a l=$ Chthamalus dalli, Scar = Semibalanus cariosus, Bnub = Balanus nubilus; for whelks: Nuc $=$ Nucella canaliculata and N. ostrina; and for limpets: Lottia $=$ Lottia spp. Diets are based on the pooled data for all feeding sea stars sampled at Strawberry Hill $(n=618)$ and the Newport Jetty $(n=607)$ between 1995 and 2005 (see 'Materials and Methods' for sampling dates). The cumulative percent at each site exceeds $100 \%$ because Pisaster often feeds on more than one prey species at a time

(authors' pers obs). Temporary declines in Pisaster density during the spring and summer (Fig. 2) were frequently associated with cold water upwelling events, during which sea stars become inactive in low zone channels and shallow subtidal water (Sanford 1999).

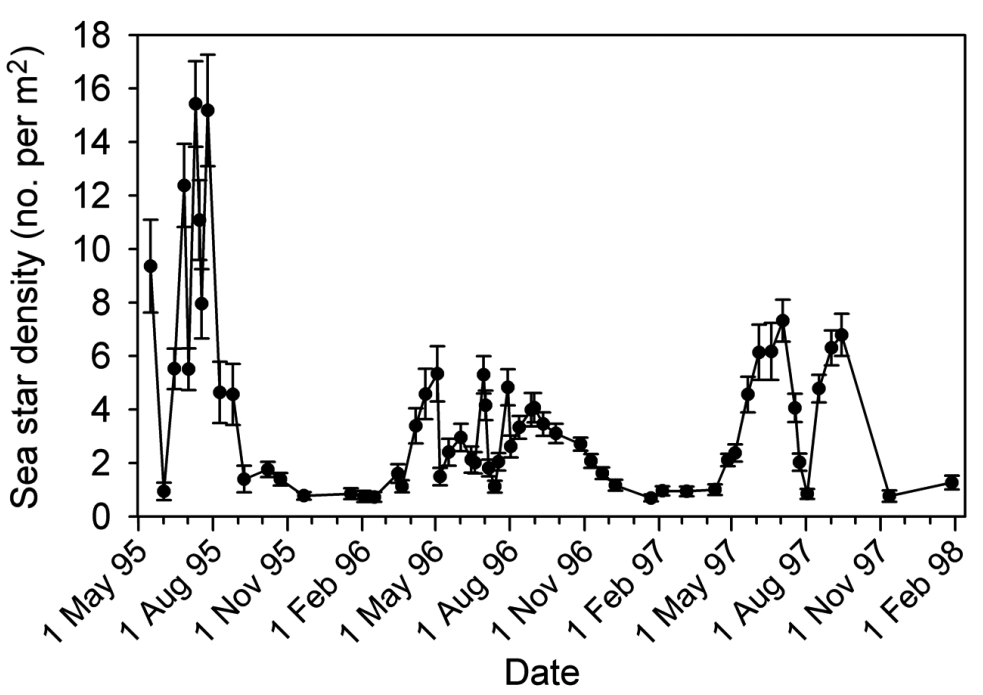

Fig. 2. Pisaster ochraceus. Seasonal variation in the density of $P$. ochraceus (mean \pm SE) in permanently marked, low intertidal plots $(n=26)$ along $1 \mathrm{~km}$ of shore at Strawberry Hill/ Bob Creek Wayside 


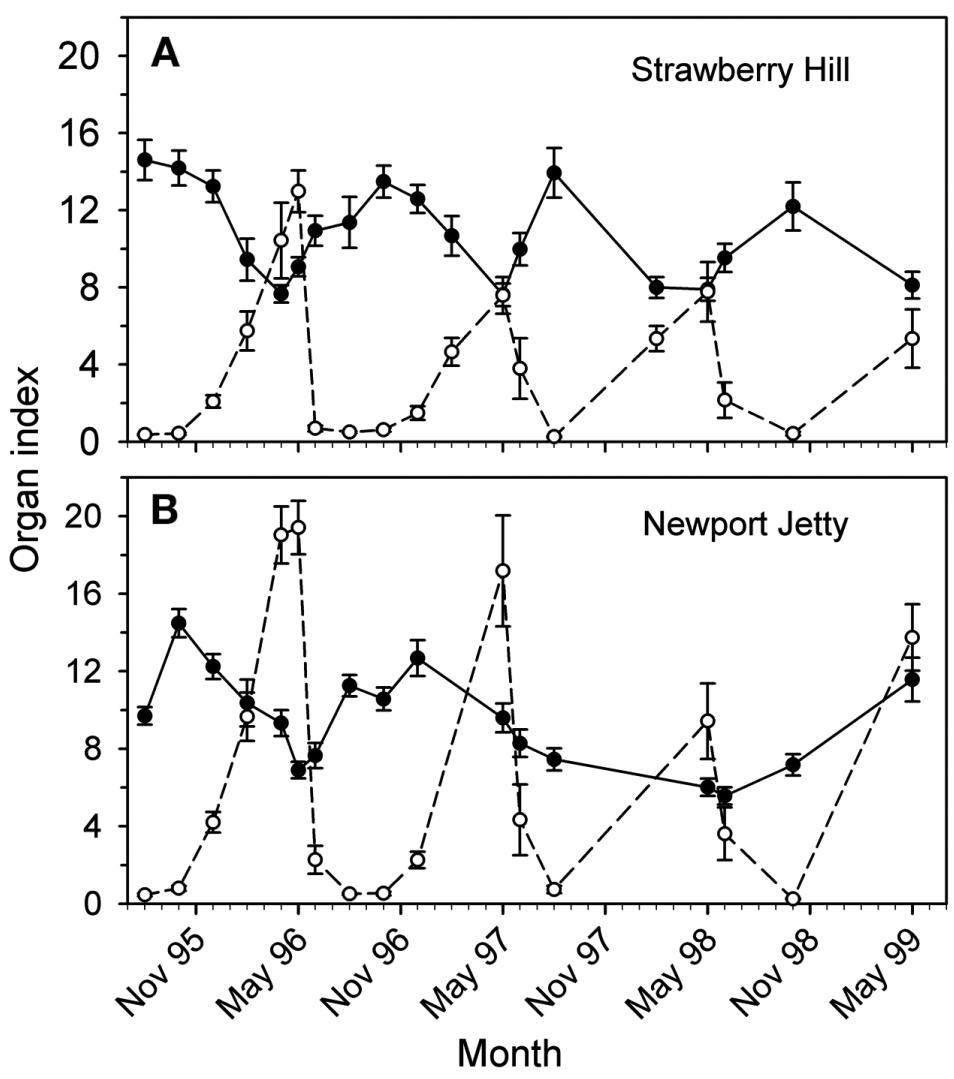

Fig. 3. Pisaster ochraceus. Cycles in pyloric caecum (solid line) and gonad indices (dashed line) on the central Oregon coast. Each point is the mean ( \pm SE) of 12 sea stars collected at (A) Strawberry Hill and (B) the Newport South Jetty between August 1995 and May 1999 between our collections of 1 May and 10 June. Pisaster were observed spawning in the field at SH and nearby sites only during this period (including 17 May 1995, 2 May 1996, 4 May 1996, 1 June 1996, 17 May 2003, 21 May 2004). Of the sea stars sampled at $\mathrm{SH}$ and NSJ, 96\% had spawned by 10 June 1996, and $75 \%$ had spawned by 10 June 1997 and 10 June 1998. Similarly, collections at SH on 19 May 2003 contained no ripe individuals (L. Petes unpubl. data). For the remaining 2 yr of the study, we assume that our samples in early May 1999 and 2005 also captured the peak gonad index, although we did not sample in early June of those years to confirm that spawning had occurred.

As predicted based on the greater prevalence of mussels in the diet at $\mathrm{SH}$, the size of the pyloric caeca in the fall was generally greater at SH than at NSJ (Fig. 4A; Table 1, Site, p <0.001). Surprisingly, despite having smaller pyloric caeca than SH sea stars, individuals at NSJ produced larger gonads in most years (Fig. 4B). At both sites, the size of the pyloric caecum index in the fall was a good predictor of gonad production during the following spring (Fig. 5). However, for any given value of the pyloric caecum index, NSJ sea stars had approximately double the gonad production (Fig. 5).

Gonad production varied markedly among years (Fig. 4B; Table 2, Year, p < 0.001). For

\section{Spatial and temporal variation in pyloric caecum and gonad indices}

At both sites, changes in pyloric caecum and gonad size were cyclical and inversely related (Fig. 3). The pyloric caecum index increased steadily over a 5 mo period (May to September), peaked in the early fall, and then shrank in size over winter as gonads were produced. Two exceptions to this general pattern occurred at NSJ: no increase in the pyloric caecum index was observed in summer 1997, and in May 1999 the pyloric caecum index was uncharacteristically high for this season (Fig. 3B).

At both sites, the gonad index peaked in early May and most individuals spawned during the period

Fig. 4. Pisaster ochraceus. Variation in Pisaster condition between Strawberry Hill and the Newport South Jetty. Bars are means $(+\mathrm{SE})$ for 12 sea stars per site; $(*)$ significant difference between sites $(t$-test, Bonferroni corrected $\mathrm{p}<0.0083)$. (A) Peak pyloric caecum index recorded during fall of each year. (B) Peak gonad index recorded in May of each subsequent year
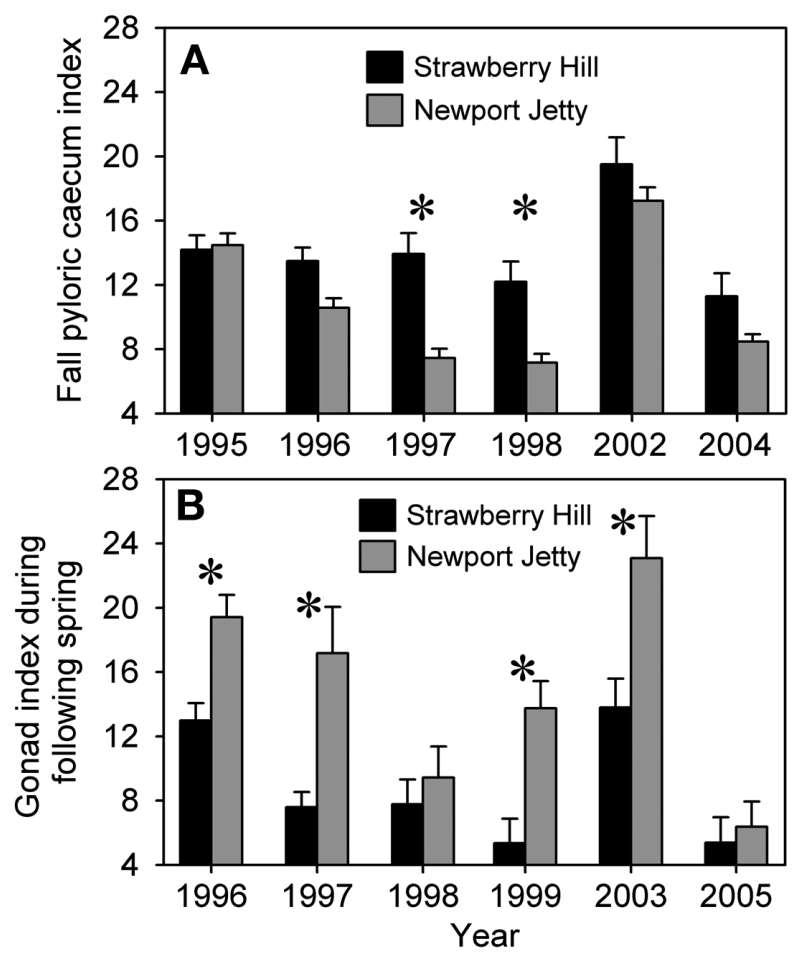


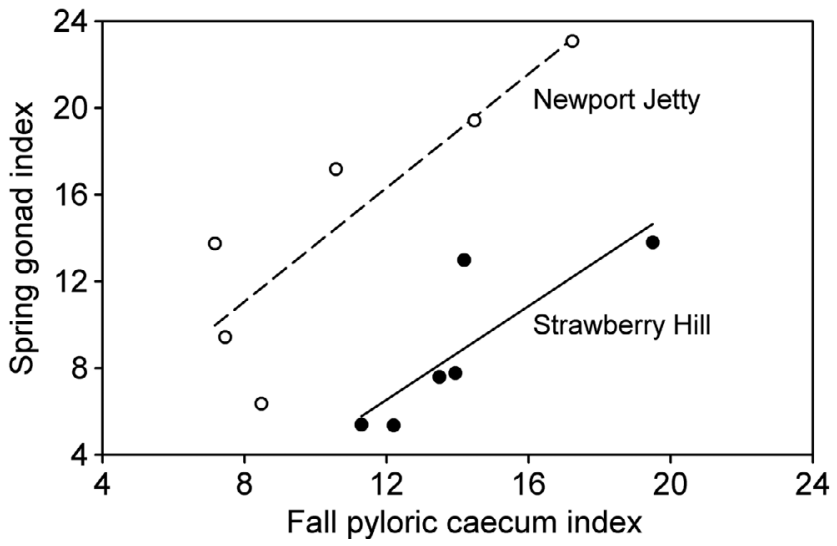

Fig. 5. Pisaster ochraceus. Relationship between size of the pyloric caeca during the fall and gonad production during the following spring. Each point represents $1 \mathrm{yr}$ at Strawberry Hill $(\mathrm{SH}, \bullet)$ and the Newport South Jetty (NSJ, o). Separate linear regressions are plotted for each site; $\mathrm{SH}$ : gonad $=(1.081 \times$ caecum $)-6.43, R^{2}=0.70, p=0.038$; for NSJ: gonad $=(1.312 \times$ caecum) $+0.570, R^{2}=0.74, p=0.028$

example, at NSJ, per capita gonad production in spring 2003 was 3.6 times greater than in spring 2005 (Fig. 4B). Similarly, at $\mathrm{SH}$, per capita gonad production in spring 2003 was 2.6 times greater than in spring 2005 . Nevertheless, gonad production was consistently greater at NSJ (Table 2, Site, $\mathrm{p}<0.001$; Site $\times$ Year, $\mathrm{p}>$ $0.05)$. There was no evidence that the spring gonad index varied between male and female sea stars (Sex, $\mathrm{p}>0.10$ ).

\section{Influence of water temperature and mussel recruitment}

Long-term monitoring at $\mathrm{SH}$ allowed us to test whether the size of the pyloric caeca attained by the end of the summer feeding season was related to variation in water temperature and/or mussel recruitment at this site. Water temperatures during the period May to August differed strongly among years in association with variation in the frequency and intensity of coastal upwelling (Table 3). Upwelling conditions (indicated by water temperatures $<10^{\circ} \mathrm{C}$ along the central Oregon coast) are frequently suppressed during El Niño years. The 1997-98 El Niño was the strongest of the century in Oregon waters (Smith et al. 2001), and cool water temperatures were uncommon at SH during summer 1997. Weaker El Niño conditions also occurred during summer 2004. In contrast, 1996 and
2002 were marked by strong upwelling seasons with a much greater frequency of cold-water events (Table 3).

As an indicator of interannual variation in Mytilus trossulus abundance, we examined mean mussel recruitment to artificial collectors deployed monthly during the period July to December. At $\mathrm{SH}$, mussels recruit to the low zone primarily during this period and become the main prey for Pisaster during the following spring/summer (Menge et al. 1994, Navarrete \& Menge 1996). During late 1994, 1995, 1996, and 1997, mussel recruitment was moderate, typically $\sim 20$ mussel recruits $\mathrm{d}^{-1}$ collector $^{-1}$ (Fig. 6). Beginning in the late 1990s there was a massive increase in Mytilus recruitment at $\mathrm{SH}$,

Table 1. Analysis of variance (ANOVA) of the effects of Site and Year on the fall pyloric caecum index for Pisaster. The response variable was log transformed prior to analysis. $\mathrm{p}$-values in bold are significant $(\mathrm{p}<0.05)$

\begin{tabular}{|lrrrc|}
\hline Source & df & SS & $F$ & p \\
\hline Site & 1 & 2.90 & 41.5 & $<\mathbf{0 . 0 0 1}$ \\
Year & 5 & 8.91 & 25.5 & $<\mathbf{0 . 0 0 1}$ \\
Site $\times$ Year & 5 & 1.92 & 5.5 & $<\mathbf{0 . 0 0 1}$ \\
Residuals & 138 & 9.64 & & \\
Total & 149 & 23.37 & & \\
\hline
\end{tabular}

Table 2. Analysis of variance (ANOVA) of the effects of Site, Year, and Sex on the spring gonad index for Pisaster

\begin{tabular}{|lrrrr|}
\hline Source & df & \multicolumn{1}{c|}{ SS } & \multicolumn{1}{c|}{$F$} & \multicolumn{1}{c|}{ p } \\
\hline Site & 1 & 1217.2 & 31.8 & $\mathbf{< 0 . 0 0 1}$ \\
Year & 5 & 2875.3 & 15.0 & $\mathbf{< 0 . 0 0 1}$ \\
Site $\times$ Year & 5 & 421.4 & 2.2 & 0.058 \\
Sex & 1 & 103.8 & 2.7 & 0.102 \\
Residuals & 131 & 5014.2 & & \\
Total & 143 & 9631.9 & & \\
\hline
\end{tabular}

Table 3. Interannual variation in water temperature, mussel recruitment, and pyloric caecum indices for Pisaster at Strawberry Hill, Oregon. Table shows percent of high tides with water temperature $<10^{\circ} \mathrm{C}$ (characteristic of upwelling), $10-12^{\circ} \mathrm{C}$, or $>12^{\circ} \mathrm{C}$ during the period May to August (the peak feeding season for Pisaster). Mussel recruitment is mean number of Mytilus recruits per collector during the period July to December of the year (i.e. 1994, 1995, etc.) prior to the primary season of Pisaster activity (spring/summer). Final column shows peak pyloric caecum index attained during early fall

\begin{tabular}{|c|c|c|c|c|c|}
\hline \multirow[t]{2}{*}{ Year } & \multicolumn{3}{|c|}{ High tide temperatures (\%) } & \multirow{2}{*}{$\begin{array}{l}\text { Mussel recruitment } \\
\left.\text { (ind. } \mathrm{d}^{-1}\right)( \pm \mathrm{SE})\end{array}$} & \multirow{2}{*}{$\begin{array}{l}\text { Pyloric caecum } \\
\text { index }\end{array}$} \\
\hline & $<10^{\circ} \mathrm{C}$ & $10-12^{\circ} \mathrm{C}$ & $>12^{\circ} \mathrm{C}$ & & \\
\hline 1995 & 23.5 & 46.9 & 29.6 & $15.2 \pm 4.1$ & 14.2 \\
\hline 1996 & 48.5 & 31.4 & 20.1 & $27.2 \pm 4.4$ & 13.5 \\
\hline 1997 & 13.8 & 33.5 & 52.7 & $22.2 \pm 3.0$ & 13.9 \\
\hline 1998 & 29.6 & 48.3 & 22.1 & $19.4 \pm 2.6$ & 12.2 \\
\hline 2002 & 64.8 & 23.2 & 12.0 & $297.3 \pm 42.6$ & 19.5 \\
\hline 2004 & 23.7 & 36.9 & 39.4 & $115.1 \pm 18.5$ & 11.3 \\
\hline
\end{tabular}




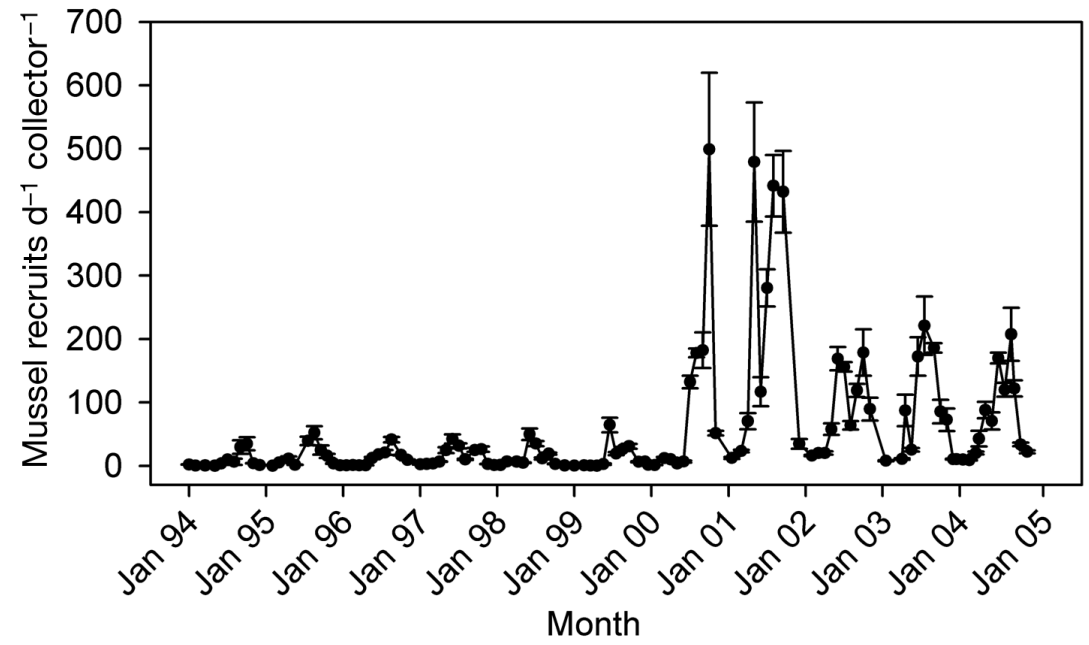

Fig. 6. Mytilus spp. Monthly mussel settlement at Strawberry Hill, 1994 to 2004. Data are mean $( \pm \mathrm{SE})$ number of mussel recruits per day from collectors $(\mathrm{n}=$ $5 \mathrm{mo}^{-1}$ ) attached in the low intertidal zone. Collectors were deployed in the same area from which Pisaster was sampled

perhaps linked to a temporary, 4 yr shift to the cold phase of the Pacific Decadal Oscillation (PDO) (B. A. Menge, J. Luchenco, F. Chan unpubl. data). Mussel abundance in collectors was an order of magnitude higher during the 2001 and 2003 recruitment seasons than during the 1994 to 1997 recruitment seasons. During the period July to December 2001, mean recruitment was nearly 300 mussel recruits $\mathrm{d}^{-1}$ collector $^{-1}$ (Table 3 ).

Despite strong variation in water temperature and mussel recruitment, the peak pyloric caecum index at $\mathrm{SH}$ varied little among years; there was no significant variation in the pyloric caecum index among fall 1995, 1996, 1997, 1998, 2004 (Fig. 4A). Severe El Niño conditions during summer 1997 did not appear to have strong impacts on either the size of the pyloric caeca or subsequent reproduction during spring 1998. However, the pyloric caecum index in fall 2002 was 37 to $73 \%$ greater than during the other $5 \mathrm{yr}$ of this study. In multiple linear regression models, neither mussel recruitment ( $p>0.20$ ) nor water temperature (proportion of high tides $<10^{\circ} \mathrm{C}$, 10 to $12^{\circ} \mathrm{C}$, or $>12^{\circ} \mathrm{C}$; p $>0.50$ in each case) explained interannual variation in the pyloric caecum index at SH. The lack of a statistical relationship was expected because there was little variation in the pyloric caecum index at $\mathrm{SH}$, except for fall 2002. However, the unusually large pyloric caeca of 2002 was coincident with a combination of massive mussel recruitment during late 2001 and frequent cold water events during summer 2002 (Table 3). The large pyloric caecum index observed in fall 2002 occurred at both sites and was followed by a per capita reproductive output that was up to 3.6 times greater than during a poor reproduction year (e.g. compare spring 2003 with spring 2005; Fig. 4B).

\section{DISCUSSION}

\section{Bottom-up effects and interannual variation in reproductive output}

Consistent with the hypothesized bottom-up effect of mussels, Pisaster at SH often developed larger pyloric caeca than sea stars at NSJ (Fig. 4A). Mussels were the dominant prey in the diet of sea stars at $\mathrm{SH}$, whereas less profitable prey (i.e. acorn barnacles; Menge 1972) were the primary prey consumed at NSJ (Fig. 1). At both sites, the pyloric caecum index at the end of the summer feeding season predicted reproductive output during the following spring (Fig. 5). As observed in previous studies of Pisaster (Feder 1956, Farmanfarmaian et al. 1958, Greenfield 1959, Mauzey 1966, Pearse \& Eernisse 1982), there was generally a cyclical, inverse relationship between the size of the pyloric caeca and the gonads. Based on this pattern, earlier authors inferred that surplus energy stored in the pyloric caeca was directed toward gonad production during the winter (Farmanfarmaian et al. 1958, Mauzey 1966). Here, we demonstrate that there is a predictive relationship between the size of the pyloric caeca in the fall and gonad volume during the following spring (Fig. 5). Thus, reproductive output at our sites appears to be determined primarily by the ability of Pisaster to accrue resources during a period of intensive feeding in the intertidal zone (between spring and early fall). As in Washington state (Mauzey 1966, Paine 1974), the intertidal abundance and activity of Pisaster at these sites declined sharply in the late fall and winter. A similar pattern has been noted previously for Pisaster in Oregon (Menge et al. 1994, Navarrete \& Menge 1996), but not for central California where Pisaster activity was reported to show no seasonal decline (Feder 1970).

Reproductive output varied by a factor of 2.5 to 3.6 among years, with productive years and poor years. In previous laboratory studies, water temperature was found to have an important influence on the feeding of Pisaster and on the size of the pyloric caeca (Sanford 2002). When raised on an ad libitum diet, sea stars held at $9^{\circ} \mathrm{C}$ generally consumed fewer mussels but developed pyloric caeca that were $25 \%$ larger than those held at $12^{\circ} \mathrm{C}$, suggesting that individuals experiencing the cool water temperatures associated with upwelling events may benefit from reduced metabolic costs (Sanford 2002). In our analyses of field collected Pisaster there was no evidence that interannual variation in water temperature alone was associated with variation 
in the size of the pyloric caeca. For example, the pyloric caecum index at $\mathrm{SH}$ differed little following summer 1996 (a cool year) and summer 1997 (a warm year during a strong El Niño event, Table 3). However, the pyloric caecum index increased substantially at $\mathrm{SH}$ during 2002 in association with unusually cool water temperatures and a striking increase in mussel settlement. These changes appeared to be linked with the PDO, which switched from a warm phase to a cool phase during 1999 to 2002 (B. A. Menge, J. Lubchenco, F. Chan unpubl. data).

Many sea stars, including Pisaster, are thought to have relatively low annual recruitment of larvae, punctuated by unusually strong settlement events in some years (Sewell \& Watson 1993, Witman et al. 2003, Blanchette et al. 2005). The observation that gonad production varied sharply among years may provide a partial explanation for annual variation in sea star settlement. Surveys of Pisaster size structure at $\mathrm{SH}$ and NSJ showed a much greater frequency of small Pisaster (<50 g wet weight) in 2003 and 2005, relative to 1995 and 1996 (E. Sanford unpubl. data). This suggests that oceanographic conditions during the period 2000 to 2002 may have been conducive to both high reproductive output of Pisaster and subsequent recruitment of juveniles onshore. Although asteroids generally have a long larval phase with high dispersal potential, previous studies suggest that in some years favorable conditions for sea star reproduction may occur over regional scales (Witman et al. 2003, Blanchette et al. 2005). For example, Witman et al. (2003) observed unprecedented recruitment of the sea star Asterias in the year following a massive subtidal recruitment of mussels to the Gulf of Maine, USA. The authors hypothesized that the unusually strong recruitment of this sea star represented a bottom-up effect of enhanced food supply on the reproductive condition of Asterias.

\section{Between-site variation in gonad production and energy allocation}

An unexpected result of our study was that sea stars at the site with higher prey quality $(\mathrm{SH})$ failed to produce larger gonads. Although sea stars at SH generally had larger pyloric caeca, NSJ sea stars produced twice as much gonadal tissue for a given size of pyloric caeca (Fig. 5). The difference in gonad production was apparent in the winter (e.g. December 1995 and February 1996; Fig. 3) indicating that the smaller May gonad index at $\mathrm{SH}$ did not arise from partial or early spawning at that site.

We propose 2 potential hypotheses to explain the between-site variation in reproductive output. First,
Pisaster at NSJ and SH may have experienced different abiotic conditions during the winter that led to greater gonad production at NSJ. Both sites are exposed outer coast sites that are subjected to storms and considerable wave swell during the winter. However, NSJ is composed of large boulders, and the spaces among boulders could have provided Pisaster with a greater refuge from wave stress than at $\mathrm{SH}$. If sea stars at NSJ expended less energy on locomotion and maintenance during the winter, they may have devoted more stored energy to gonad production.

Similarly, Pisaster at NSJ may have continued feeding during the winter in the subtidal recesses of the jetty. There is some evidence that sea stars can transfer ingested nutrients directly to the developing gonads without involvement of the pyloric caeca (Beijnink \& Voogt 1984). Thus, if sea stars consumed greater subtidal resources during the winter months at NSJ than at $\mathrm{SH}$, these extra resources may have been devoted to increased gonad production without any changes in the pyloric caecum index. During the late fall and winter, Pisaster in Oregon and Washington state become less active and retreat to the very low intertidal or shallow subtidal zone (Mauzey 1966, Paine 1974, Menge 1992, Menge et al. 1994, Navarrete \& Menge 1996). This seasonal change in distribution was observed at both SH and NSJ (Fig. 2; authors' pers. obs.). Although feeding activity is reduced during the winter months, some feeding continues throughout the winter (Mauzey 1966, Navarrete \& Menge 1996, authors' unpubl. data). Unfortunately, the high wave energy of our sites made it dangerous to collect data on the diet and activity of Pisaster in the shallow subtidal zone, particularly during the winter. However, the ability of the fall pyloric caecum index to predict peak gonad production (independent of any information on winter feeding; Fig. 5), suggests that energy stored during the summer feeding season is the major determinant of annual reproductive output in this species.

An alternative hypothesis to explain the betweensite differences in reproductive output is that sea stars at NSJ may have allocated more energy to reproduction than individuals at SH. In echinoderms, energy may be allocated to maintenance, growth, and reproduction, and the pattern of allocation may be a complex function of demographic and environmental factors (Harrold \& Pearse 1980, Ebert 1982, Lawrence $1985,1987)$. Differences between sites in allocation to reproduction could have resulted if we sampled sea stars that were different ages. Although we restricted sampling of Pisaster to a narrow size range (170 to $260 \mathrm{~g}$ wet weight), it is possible that sea stars of this size were older at NSJ than at SH. Unfortunately, most sea stars cannot be aged based on size or skeletal structures (but see Stump \& Lucas 1990), and individ- 
uals are notoriously difficult to tag. However, Pisaster are estimated to live longer than $20 \mathrm{yr}$ (Menge 1975). It is possible that sea stars at $\mathrm{SH}$ grow faster than those at NSJ because of the greater availability of Mytilus trossulus. In an earlier experiment, Pisaster maintained in laboratory tanks on an ad libitum diet of $M$. trossulus doubled their wet weight in 2 mo (from 130 to $260 \mathrm{~g}$ ) (Sanford 2002). At NSJ, where Pisaster feeds primarily on less productive prey (i.e. acorn barnacles; Menge 1972, 1975), individuals may take longer to reach a given size than their counterparts at $\mathrm{SH}$.

Empirical studies of marine invertebrates suggest that younger individuals often allocate greater resources to somatic growth than reproduction (Thompson 1979, Kettle \& Lucas 1987). As individuals age, resources are increasingly channeled to reproduction, and the gonad index increases. An age-related increase in reproductive effort has been documented in echinoderms, including the crown-of-thorns sea star Acanathaster planci and some echinoids (Thompson 1979, Lawrence 1985, Kettle \& Lucas 1987, Stump \& Lucas 1990). This life history strategy may be a response to selection imposed by the disadvantages of small body size (e.g. reduced competitive ability, reduced foraging efficiency, and/or greater predation on small individuals). Mortality in Pisaster is estimated to be high in juvenile sea stars (Menge 1975, Sewell \& Watson 1993), suggesting that younger individuals may be selected to direct more resources towards somatic growth than reproduction.

Theoretical work also suggests that reproductive effort may increase with age in iteroparous animals with reproductive senility (Roff 2002). Older individuals may be selected to invest more in current fecundity because the expectation of future offspring production decreases with age (Pianka \& Parker 1975). Although there are empirical data to support this prediction in vertebrate ectotherms (Roff 2002, McIntyre \& Hutchings 2003), there is less information about age-specific fecundity in invertebrates (but see Thompson 1979, Kettle \& Lucas 1987, Stump \& Lucas 1990). Reproductive senility has been observed in sea stars (Lucas 1984) and some sea urchins (Lawrence 1987, but see Ebert \& Southon 2003) but has not been studied in Pisaster. Further studies are needed to explore whether between-site variation in age structure may influence patterns of reproductive allocation.

\section{Implications for identifying source populations}

The potential for a site to act as a reproductive source may depend on a variety of factors including population density, age and size structure, total population size, per capita reproductive output, and local hydrodynamics (Denny et al. 1992, Levitan et al. 1992, Quinn et al. 1993, Kido \& Murray 2003, Wing et al. 2003, Leslie et al. 2005). Overall, our results suggest that Pisaster at NSJ had consistently higher per capita reproduction than those at $\mathrm{SH}_{\text {, despite considerable }}$ variation among years in oceanographic conditions and reproductive output. This result lends support to the idea that reproductive source populations may be spatially and temporally consistent for a given species. Siting marine reserves to protect such populations may help replenish non-protected areas through larval export (Rogers-Bennett et al. 1995, Roberts 1997, Crowder et al. 2000). However, in our study, the population with greater per capita reproductive output was found at the site with lower quality prey. This counter-intuitive result suggests that identifying source populations may be more complex than simply protecting sites with high quality resources and strong bottom-up influences. Rather, predicting patterns of per capita reproductive output may require a more detailed understanding of how demographic and environmental factors influence the allocation of resources to maintenance, growth, and reproduction. The importance of these factors may be particularly strong for long-lived iteroparous consumers.

Acknowledgements. We thank Hatfield Marine Science Center for use of its laboratory facilities, and B. Daley, M. Foley, G. Hudson, M. Robart, and many student assistants for help deploying and processing mussel recruitment collectors. Comments from E. S. L. Kuo, H. Leslie, J. Sones, and 4 anonymous reviewers greatly improved this manuscript. Funding was provided to E.S. from a National Science Foundation graduate research fellowship and from the University of California, Davis. Funding was provided to B.A.M. from the Wayne and Gladys Valley Foundation, the Andrew W. Mellon Foundation, the David and Lucile Packard Foundation, and the Gordon and Betty Moore Foundation. This is contribution number 261 of the Partnership for Interdisciplinary Studies of Coastal Oceans (PISCO), and contribution number 2386 of the Bodega Marine Laboratory, University of California, Davis, USA.

\section{LITERATURE CITED}

Barker MF, Xu RA (1991) Population differences in gonad and pyloric caeca cycles of the New Zealand sea star Sclerasterias mollis (Echinodermata: Asteroidea). Mar Biol 108: 97-103

Barth JA, Menge BA, Lubchenco J, Chan F and others (2007) Delayed upwelling alters nearshore coastal ocean ecosystems in the northern California current. Proc Natl Acad Sci USA 104:3719-3724

Beijnink FB, Voogt PA (1984) Nutrient translocation in the sea star: whole-body and microautoradiography after ingestion of radiolabeled leucine and palmitic acid. Biol Bull 167:669-682

Bertness MD, Gaines SD, Bermudez D, Sanford E (1991) Extreme spatial variation in the growth and reproductive 
output of the acorn barnacle Semibalanus balanoides. Mar Ecol Prog Ser 75:91-100

Blanchette CA, Richards DV, Engle JM, Broitman BR, Gaines SD (2005) Regime shifts, community change and population booms of keystone predators at the Channel Islands. Proceedings of the 6th California Islands Symposium 6: 435-441

Carr MH, Neigel JE, Estes JA, Andelman SJ, Warner RR, Largier JL, Lubchenco J (2003) Comparing marine and terrestrial ecosystems: implications for principles of reserve design in coastal marine ecosystems. Ecol Appl 13: S90-S107

Crowder LB, Lyman SJ, Figueira WF, Priddy J (2000) Sinksource population dynamics and the problem of siting marine reserves. Bull Mar Sci 66:799-820

Crump RG (1971) Annual reproductive cycles in 3 geographically separated populations of Patiriella regularis (Verrill), a common New Zealand asteroid. J Exp Mar Biol Ecol 7: $137-162$

Denny M, Dairikij J, Distefano S (1992) Biological consequences of topography on wave-swept rocky shores: I. Enhancement of external fertilization. Biol Bull 183: $220-232$

Ebert TA (1982) Longevity, life history, and relative body wall size in sea urchins. Ecol Monogr 52:353-394

Ebert TA, Southon JR (2003) Red sea urchins (Strongylocentrotus franciscanus) can live over 100 years: confirmation with A-bomb ${ }^{14}$ carbon. Fish Bull 101:915-922

Eckert G, Engle JM, Kushner D (1999) Sea star disease and population declines at the Channel Islands. Proceedings of the 5th California Islands Symposium 5:390-393

Farmanfarmaian A, Giese AC, Boolootian RA, Bennett J (1958) Annual reproductive cycles in four species of west coast starfishes. J Exp Zool 138:355-367

Feder HM (1956) Natural history studies on the starfish Pisaster ochraceus (Brandt, 1835) in the Monterey Bay area. PhD dissertation, Stanford University, CA

Feder HM (1970) Growth and predation by the ochre sea star, Pisaster ochraceus (Brandt), in Monterey Bay, California. Ophelia 8:161-185

Greenfield LJ (1959) Biochemical and environmental factors involved in the reproductive cycle of the sea star Pisaster ochraceus (Brandt). PhD dissertation, Stanford University, CA

Harrold C, Pearse JS (1980) Allocation of pyloric caecum reserves in fed and starved sea stars, Pisaster giganteus (Stimpson): somatic maintenance comes before reproduction. J Exp Mar Biol Ecol 48:169-183

Kettle BT, Lucas JS (1987) Biometric relationships between organ indices, fecundity, oxygen consumption and body size in Acanthaster planci (L.) (Echinodermata, Asteroidea). Bull Mar Sci 41:541-551

Kido JS, Murray SN (2003) Variation in owl limpet Lottia gigantea population structures, growth rates, and gonadal production on southern California rocky shores. Mar Ecol Prog Ser 257:111-124

Lawrence JM (1985) The energetic echinoderm. In: Keegan BF, O'Connor DS (eds) Echinodermata. Balkema Press, Rotterdam, p 47-67

Lawrence JM (1987) A functional biology of echinoderms. John Hopkins University Press, Baltimore, MD

Lawrence JM, Lane JM (1982) The utilization of nutrients by post-metamorphic echinoderms. Jangoux $M$, Lawrence JM (eds) Echinoderm nutrition. Balkema Press, Rotterdam, p 331-371

Leighton BJ, Boom JDG, Bouland C, Hartwick EB, Smith MJ (1991) Castration and mortality in Pisaster ochraceus par- asitized by Orchitophrya stellarum (Ciliophora). Dis Aquat Org 10:71-73

Leslie HM, Breck EN, Chan F, Lubchenco J, Menge B (2005) Barnacle reproductive hotspots linked to nearshore ocean conditions. Proc Natl Acad Sci USA 102:10534-10539

Levitan DR, Sewell MA, Chia FS (1992) How distribution and abundance influence fertilization success in the sea urchin Strongylocentrotus franciscanus. Ecology 73:248-254

Lucas JS (1984) Growth, maturation and effects of diet in Acanthaster planci (L.) (Asteroidea) and hybrids reared in the laboratory. J Exp Mar Biol Ecol 79:129-147

Mauzey KP (1966) Feeding behavior and reproductive cycles in Pisaster ochraceus. Biol Bull 131:127-144

McIntyre TM, Hutchings JA (2003) Small-scale temporal and spatial variation in Atlantic cod (Gadus morhua) life history. Can J Fish Aquat Sci 60:1111-1121

Menge BA (1972) Foraging strategy of a starfish in relation to actual prey availability and environmental predictability. Ecol Monogr 42:25-50

Menge BA (1975) Brood or broadcast? The adaptive significance of different reproductive strategies in the two intertidal sea stars Leptasterias hexactis and Pisaster ochraceus. Mar Biol 31:87-100

Menge BA (1992) Community regulation: under what conditions are bottom-up factors important on rocky shores? Ecology 73:755-765

Menge BA (2000) Top-down and bottom-up regulation of marine rocky intertidal communities. J Exp Mar Biol Ecol 250:257-289

Menge BA, Berlow EL, Blanchette CA, Navarrete SA, Yamada SB (1994) The keystone species concept: variation in interaction strength in a rocky intertidal habitat. Ecol Monogr 64:249-286

Menge BA, Daley BA, Wheeler PA, Dahlhoff E, Sanford E, Strub PT (1997) Benthic-pelagic links in rocky intertidal communities: bottom-up effects on top-down control? Proc Natl Acad Sci USA 94:14530-14535

Morgan SG (2001) The larval ecology of marine communities. In: Bertness MD, Gaines SD, Hay ME (eds) Marine community ecology. Sinauer Associates, New York, p 159-181

Navarrete SA, Menge BA (1996) Keystone predation and interaction strength: interactive effects of predators on their main prey. Ecol Monogr 66:409-429

Paine RT (1974) Intertidal community structure: experimental studies on the relationship between a dominant competitor and its principal predator. Oecologia 15:93-120

Pearse JS, Eernisse DJ (1982) Photoperiodic regulation of gametogenesis and gonadal growth in the sea star Pisaster ochraceus. Mar Biol 67:121-125

Pianka ER, Parker WS (1975) Age specific reproductive tactics. Am Nat 109:453-464

Quinn JF, Wing SR, Botsford LW (1993) Harvest refugia in marine invertebrate fisheries: models and applications to the red sea urchin, Strongylocentrotus franciscanus. Am Zool 33:537-550

Roberts CM (1997) Connectivity and management of Caribbean coral reefs. Science 278:1454-1457

Roberts CM (1998) Sources, sinks and the design of marine reserve networks. Fisheries 23:16-19

Roff DA (2002) Life history evolution. Sinauer Associates, Sunderland, MA

Rogers-Bennett L, Bennett WA, Fastenau HC, Dewees CM (1995) Spatial variation in red sea urchin reproduction and morphology: implications for harvest refugia. Ecol Appl 5:1171-1180

Sala E, Aburto O, Paredes G, Parra I, Barrera JC, Dayton PK (2002) A general model for designing networks of marine 
reserves. Science 298:1991-1993

Sanford E (1999) Regulation of keystone predation by small changes in ocean temperature. Science 283: 2095-2097

Sanford E (2002) The feeding, growth and energetics of two rocky intertidal predators (Pisaster ochraceus and Nucella canaliculata) under water temperatures simulating episodic upwelling. J Exp Mar Biol Ecol 273:199-218

Sanford E, Menge BA (2001) Spatial and temporal variation in barnacle growth in a coastal upwelling system. Mar Ecol Prog Ser 209:143-157

Sewell MA, Watson JC (1993) A 'source' for asteroid larvae?: recruitment of Pisaster ochraceus, Pycnopodia helianthoides and Dermasterias imbricata in Nootka Sound, British Columbia. Mar Biol 117:387-398

Smith RL, Huyer A, Fleischbein J (2001) The coastal ocean off Oregon from 1961 to 2000: is there evidence of climate change or only of Los Niños? Prog Oceanogr 49:63-93

Stump RJW, Lucas JS (1990) Linear growth in spines from

Editorial responsibility: Howard Browman (Associate Editorin-Chief), Storebø, Norway
Acanthaster planci (L.) involving growth lines and independent pigment bands. Coral Reefs 9:149-154

Thompson RJ (1979) Fecundity and reproductive effort in the blue mussel (Mytilus edulis), the sea urchin (Strongylocentrotus droebachiensis), and the snow crab (Chionoecetes opilio) from populations in Nova Scotia and Newfoundland. Can J Fish Aquat Sci 36:955-964

Wing SR, Gibbs MT, Lamare MD (2003) Reproductive sources and sinks within a sea urchin, Evechinus chloroticus, population of a New Zealand fjord. Mar Ecol Prog Ser 248: $109-123$

Witman JD, Smith F (2003) Rapid community change at a tropical upwelling site in the Galápagos Marine Reserve. Biodivers Conserv 12:24-45

Witman JD, Genovese SJ, Bruno JF, McLaughlin JW, Pavlin BI (2003) Massive prey recruitment and the control of rocky subtidal communities on large spatial scales. Ecol Monogr 73:441-462

Submitted: December 22, 2006; Accepted: July 20, 2007 Proofs received from author(s): September 17, 2007 